\title{
Changes of agouti-related protein in hypothalamus, placenta, and serum during pregnancy in the rat
}

\author{
Dawid Szczepankiewicz, Ewa Pruszyńska-Oszmałek, Przemysław Kaczmarek, Marek Skrzypski, \\ Karolina Andrałojć, Tatiana Wojciechowicz, Maciej Sassek and Krzysztof W Nowak
}

Department of Animal Physiology and Biochemistry, Poznań University of Life Sciences, 35 Wołyńska Street, 60-637 Poznań, Poland

(Correspondence should be addressed to D Szczepankiewicz; Email: dawidsz@up.poznan.pl)

\begin{abstract}
Agouti-related protein (AGRP) is a homolog of the agouti protein and acts as an antagonist of peptides derived from propiomelanocortin through melanocortin receptors. This peptide is produced mainly in the hypothalamus, particularly during negative energy balance and influences increased food intake. In the hypothalamus, this peptide is co-expressed in arcuate nuclei with neuropeptide $\mathrm{Y}$, another important peptide that regulates energy metabolisms. In our study, we analyzed changes in the Agrp mRNA level in the hypothalamus as well as mRNA and protein levels in placenta during different stages of rat pregnancy. We also
\end{abstract}

investigated the AGRP level in the blood serum. In this study, we found the AGRP level in serum increased, while its gene expression in the hypothalamus increased only up to the 13th day of pregnancy, and decreased on the 18th day. This study demonstrates that AGRP is expressed during late pregnancy in placenta. Moreover, we found that AGRP expression is higher on the 18th than on the 13th day of pregnancy. Our results indicate that AGRP may play an important role during pregnancy in the mother's and, possibly, also in the fetus's energy balance.

Journal of Endocrinology (2009) 202, 35-41

\section{Background}

Peptides derived from propiomelanocortin prohormone (POMC), after posttranslational modifications, particularly $\alpha$ melanocyte-stimulating hormone $(\alpha \mathrm{MSH})$, regulate appetite in the central nervous system by decreasing food intake (Kim et al. 2002, Pritchard et al. 2002). In 1997, a protein with a high homology to agouti protein was identified and called agouti-related protein (AGRP). This protein is an antagonist to melanocortin receptors, mainly $\mathrm{MC} 3 \mathrm{R}$ and $\mathrm{MC} 4 \mathrm{R}$ (Ollmann et al. 1997, Shutter et al. 1997, Pritchard et al. 2004). This type of receptor is the most common isoform in the brain and is responsible for appetite regulation (Yeo et al. 1998). This may indicate that AGRP is essential in the regulation of energy balance.

It was found that AGRP expression is associated with changes in the leptin level, one of the main hormones which regulates food intake via the hypothalamus. It was further observed that AGRP is produced in neurons that exhibit leptin receptor expression. Mizuno et al. (1999) reported that Agrp mRNA production was inhibited by leptin injection into the hypothalamus. They also found that the AGRP level was fivefold higher in ob/ob mice. Moreover, AGRP may also influence augmentation of the POMC expression (Schwartz et al. 1997, Korner et al. 1999, Cowley et al. 2001). However, in the ob/ob mouse model, changes in the AGRP expression are more significant than the POMC expression
(Ollmann et al. 1997, Thornton et al. 1997). In addition, Hoggard et al. (2004) also demonstrated that $\alpha \mathrm{MSH}$ reduced leptin secretion from adipocytes, but this action of MSH was inhibited by the addition of AGRP. On the other hand, there were no changes of the leptin expression level upon AGRP stimulation in the absence of $\alpha \mathrm{MSH}$. These data suggest that there is a feedback loop between leptin and $\alpha \mathrm{MSH}$, and that AGRP may exert a significant effect on the regulation of this mechanism, and hence, on the nutritional status.

Moreover, AGRP is co-expressed in Arcuate nuclei with neuropeptide Y (NPY), another orexigenic peptide (Hahn et al. 1998, Chen et al. 1999). This indicates that changes in energy expenditure regulated by other hormones similar to leptin and insulin may also be associated with changes in NPY expression (Schwartz et al. 1996, Ollmann et al. 1997, Shutter et al. 1997, Korner et al. 2001, van den Top et al. 2004). Moreover, both insulin and leptin exert similar effects and inhibit the expression of AGRP and NPY. It was further shown that NPY also stimulates food intake by inhibiting POMC secretion (Cowley et al. 1999). These are important data indicating the crucial role of AGRP in the regulation of energy balance.

Hypothalamic AGRP and NPY also mediate the action of ghrelin, another peptide regulating food intake, which is produced in the stomach and in the hypothalamus (Kojima et al. 1999, Kamegai et al. 2001, Seoane et al. 2003, Chen et al. 2004). Results published by Chen et al. (2004) demonstrated 


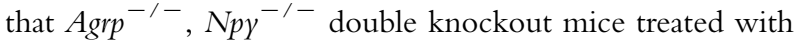
ghrelin had a 4-h food intake attenuation. However, in a mouse model with one gene knocked out, either Agrp or Npy, there was no attenuation of food intake. These results indicated that AGRP may play an important role in appetite regulation. On the other hand, Tang-Christensen et al. (2004) found that NPY has a short-term effect on food intake, whereas the effect mediated by AGRP is prolonged. Moreover, mice with knockout of MC3R and MC4R genes did not show increased food intake after ghrelin stimulation, which may additionally imply the importance of AGRP in food intake regulation (Shaw et al. 2005).

All these data suggest the importance of AGRP in the regulation of energy status in relation to numerous peptides. In our study, we presented changes in the expression of Agrp in the hypothalamus, and its protein level in serum during hypermetabolic state, which is observed during pregnancy. Moreover, we present here that AGRP is also expressed in placenta during late pregnancy, which not only may influence energy homeostasis in the mother, but also may affect fetus development.

\section{Material and Methods}

\section{Animals}

In this experiment, female Wistar rats were used. Vaginal smear analysis was executed every day at the same time of day. The presence of sperm was defined as the first day of pregnancy. After fertilization, pregnant rats were kept under conditions described previously (Szczepankiewicz et al. 2006). Experimental rats were analyzed on day 4 (before implantation and placenta development, group B), day 13 (embryonic period, group C), day 18 (fetal period, group D) and one day after parturition (group E), as suggested by Witschi (1962). Rats in the diestrus phase of estrous cycle were used as controls (group A). In each group, ten animals were used. The Local Ethics Committee for Experiments on Animals approved the experiment protocol.

\section{$R I A$}

Serum was collected immediately after decapitation and frozen at $-80{ }^{\circ} \mathrm{C}$. AGRP was measured using a specific RIA kit (Phoenix Peptide, Karlsruche, Germany) according to the manufacturer's protocol. Intra- and inter-assays were $4 \cdot 3$ and $9 \cdot 2 \%$ respectively.

\section{Immunocytochemistry}

Placenta was cut out after decapitation from the mother on the 13th and 18th days of pregnancy. Placental tissue was fixed in the Bouin's fluid and incubated for $72 \mathrm{~h}$. Then it was embedded in paraffin and sectioned at $6 \mu \mathrm{m}$. After deparaffinization of sections, blocking of endogenous peroxidase activity was carried out by incubation in $1 \%$ $\mathrm{H}_{2} \mathrm{O}_{2}$ for $30 \mathrm{~min}$ at room temperature. In the next step, the sections were washed in PBS. After washing, the sections were preincubated for $30 \mathrm{~min}$ with $5 \%$ normal goat serum (DAKO, Glostrup, Denmark). A total of 1\% of BSA (SigmaAldrich) was added to the goat serum. After that, the sections were incubated with a goat anti-rat AGRP (Phoenix Peptide), or in its solvent as a negative control for $1 \mathrm{~h}$ and then they were washed in PBS. Sections were incubated with peroxidase and secondary antibody (DAKO LSAB 2 System HRP). Peroxidase activity was detected using the DAB technique (DAKO liquid DAB substrate - chromogen system) and nuclei were counterstained with hematoxylin. A negative control without the primary antibody step was prepared. Observation was done with use of Zeiss LSM 510 Meta and analysis of figures was performed with use of LSM 510 vs 3.2 SP1 software.

\section{$R N A$ isolation and reverse transcription}

Total RNA from the placenta and hypothalamus was isolated using Trizol LS Reagent (Invitrogen Corp.) according to the manufacturer's protocol. After RNA isolation, DNase digestion was performed using RQ1 RNase-Free DNase (Promega Corp). The quantity and quality of RNA were analyzed using an Eppendorf spectrophotometer (Eppendorf AG, Hamburg, Germany). A total of $2 \mu \mathrm{g}$ RNA were used to perform the reverse transcription (RT)-PCR analysis. RT was executed using an ImProm-II RT System (Promega Corp). Negative controls without RT that has been used in further analysis were also prepared.

\section{Real-time PCR}

Primers for the Agrp and internal standard hypoxanthine phosphoribosyl transferase (Hprt) were designed using Primer 3 software accessible in the internet to allow the amplification of regions that span introns. Sequence divisions on exonintron boundaries were analyzed using the 'Blat' option from the internet page UCSC Genome Browser Home

Table 1 PCR primers and number of probes

Primer sequences

Gene

$\operatorname{Agrp~(AF\_ 206017)~}$

Hprt (NM_012583)
Forward 5' CAGCAGACCGAGCAGAAGATGT 3' Reverse 5' GCACAGGTCGCAGCAAGGT 3' Forward 5' CAGTCAACGGGGGACATAAAAG $3^{\prime}$ Reverse 5' ATTTTGGGGCTGTACTGCTTGA 3'
Roche probes number

$\# 29$

$\# 22$ 
(www.genome.ucsc.edu) for the rat. For the designed primers, we adjusted universal Tag Man probes (Roche Diagnostic) employing the Universal Probe Finder available on the Roche Internet Homepage. The probe numbers that we used were \# 29 and \# 22 for the Agrp (AF_206017) and Hprt (NM_012583) respectively (Table 1). The internal standard was selected from five genes (data not shown) after Best Keeper analysis (Pfaffl et al. 2004). Real-time expression was prepared using a LightCycler 2.0 instrument (Roche Diagnostic) and a LightCycler TaqMan Master kit (Roche Diagnostic). After initial optimization, the product was recovered from capillaries and resolved on $2 \%$ agarose gel at the presence of DNA molecular standard (Promega Corp). Afterwards the products were photographed and analyzed using Gel Logic 100 Imaging System and Kodak 1D analysis software version 3.6 (Estman Kodak Company) to verify the correct product size. Quantification was made using the relative standard curve method.

\section{Sequencing of Agrp}

In addition, real-time PCR with SYBR Green using LightCycler Fast Start DNA Master SYBR Green I kit (Roche Diagnostic) was performed. Melting curve analysis was also done. The product was recovered from capillaries and resolved in agarose. The PCR products for Agrp were cut out from gel and purified using DNA Gel extraction kit (Millipore, Billerica, MA, USA). Afterwards, the product was sequenced by IBB PAN (Warsaw, Poland) using ABI Prism BigDye terminator cycle sequencing kit to confirm the presence of Agrp products.

\section{Western blotting}

Total protein was isolated simultaneously with total RNA from placenta according to the manufacturer's protocol. Protein quantity was analyzed using Bradford reagent (SigmaAldrich Inc.) and measured on a spectrophotometer (Eppendorf AG). Equal amounts of proteins $(8 \mu \mathrm{g})$ were used in the analysis. Samples were heated with XT Sample Buffer and XT Reducing Agent (Bio-Rad) at $95^{\circ} \mathrm{C}$ for $5 \mathrm{~min}$ and loaded onto a 12\% Criterion XT Precast Gel (Bio-Rad). Protein electrophoresis was performed using Bio-Rad Criterion apparatus in electron transfer XT Mops Running Buffer (Bio-Rad). The protein molecular mass standards Cruz Marker MW Standards (Millipore) were used. We performed wet electrotransfer of proteins from the gel to PVDF membranes (Millipore) for $1 \mathrm{~h}$ at $50 \mathrm{~V}$ at $4{ }^{\circ} \mathrm{C}$ using TransBlot Cell (Bio-Rad). The transfer efficiency was verified by incubating part of the gel with repeated sample in a Coomasie Brilliant Blue (Sigma-Aldrich Inc.) solution. Nonspecific protein binding was reduced during overnight incubations in blocking buffer ( $2 \%$ BSA in TBST). The membranes were incubated with specific goat antibodies, anti-rat AGRP (Santa Cruz Biotechnology, Santa Cruz, CA, USA). After washing in a TBST buffer, immunoreactive complex

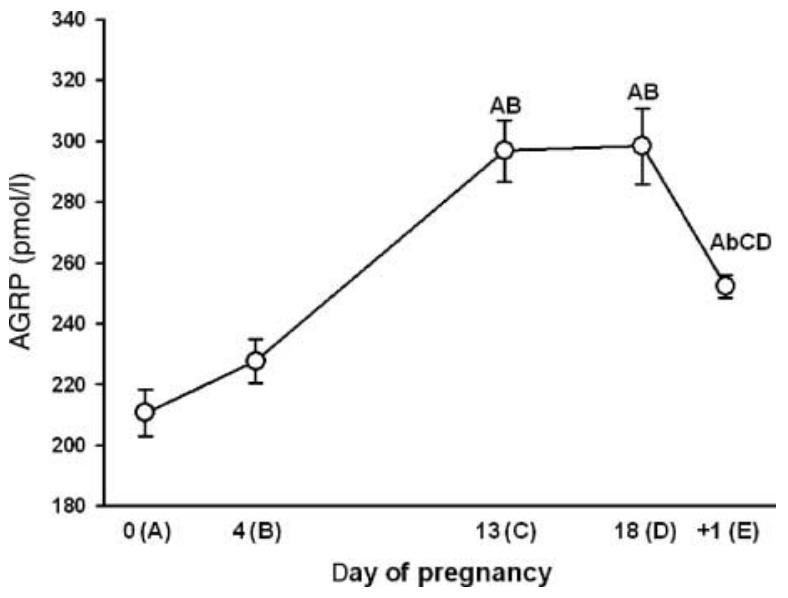

Figure 1 Changes of AGRP concentration in blood serum of the pregnant rats. Statistically significant differences are marked with letters corresponding to the groups (small letters $-p \leq 0 \cdot 05$, capital letters $-P \leq 0 \cdot 01)$. $P=0 \cdot 05$ is not statistically significant.

was detected with secondary donkey anti-goat IgGs conjucted to HRP and Immobilon Western Chemiluminescent HRP Substrate (Millipore). Western blots were visualized and analyzed using Versa Doc apparatus and quantity one 1-D analysis software (Bio-Rad). Negative controls with blocking peptides (Santa Cruz Biotechnology) against AGRP were also performed.

\section{Statistical analysis}

Statistical analysis for the AGRP level in serum and its expression in the hypothalamus was performed using ANOVA, followed by the multiple range Duncan's test with 99 and 95\% confidence intervals. For the Agrp expression in placenta, the $t$-test was used. Results were shown as means \pm s.E.M.

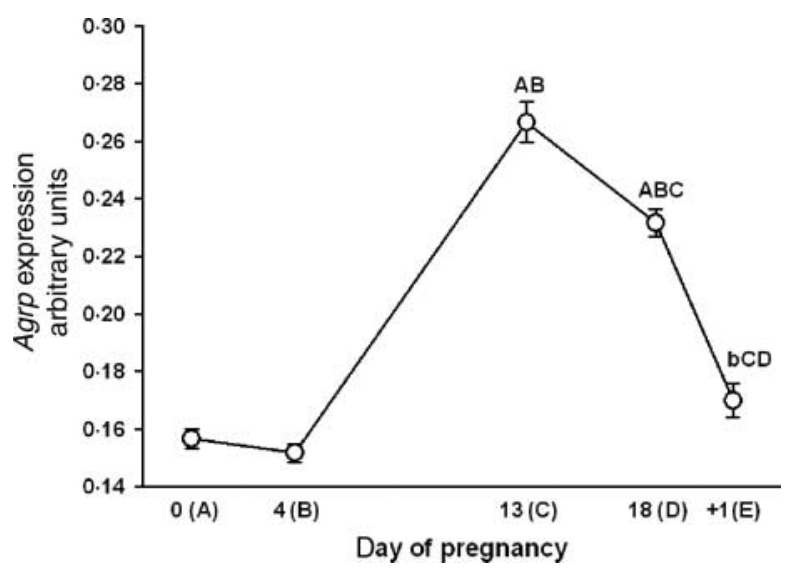

Figure 2 Changes in hypothalamic expression of Agrp in the course of pregnancy. Statistically significant differences are marked with letters corresponding to the groups (small letters $-p \leq 0 \cdot 05$, capital letters $-P \leq 0 \cdot 01) . P=0.05$ is not statistically significant. 

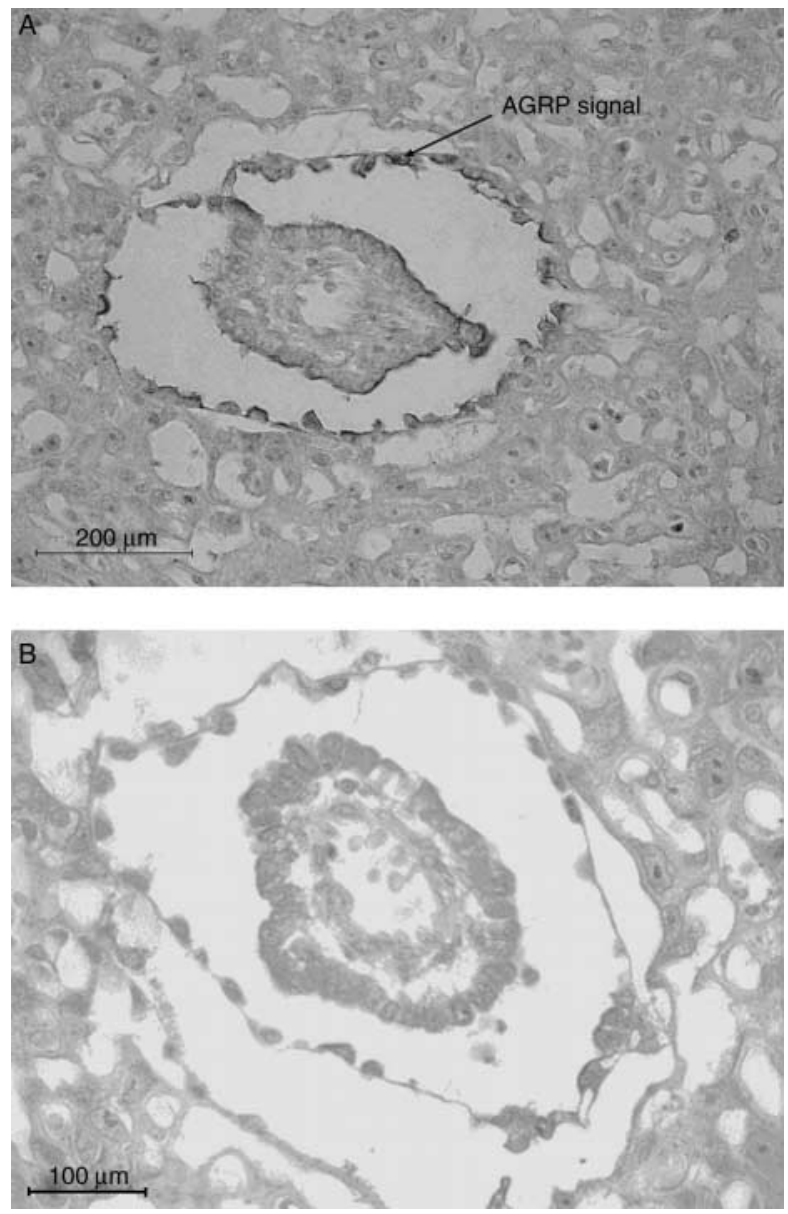

Figure 3 (A) Immunocytochemistry localization of AGRP in 18th day of pregnancy in placenta. (B) Control reaction.

\section{Results}

In our study, we found that AGRP level in the serum increased significantly on the 13th and 18th days of pregnancy, and there was a slight increase on the 4th day in comparison with controls and a decrease after delivery, but its level was still higher than in control rats (Fig. 1).

The expression of Agrp in the hypothalamus increased substantially in the course of pregnancy. After 18 days, we found extenuation of mRNA level for Agrp (Fig. 2).

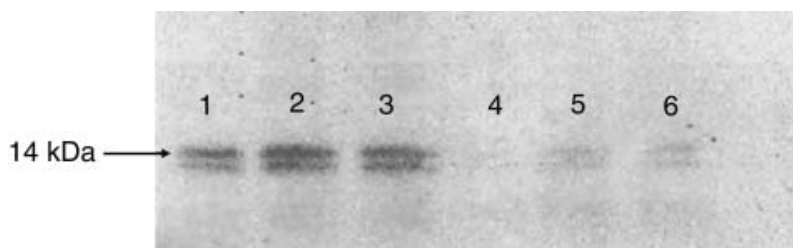

Figure 4 Western blotting of placental AGRP in 13th and 18th days of pregnancy. Lanes 1-3 present 18th day of pregnancy; lanes 4-6 present 13th day of pregnancy.

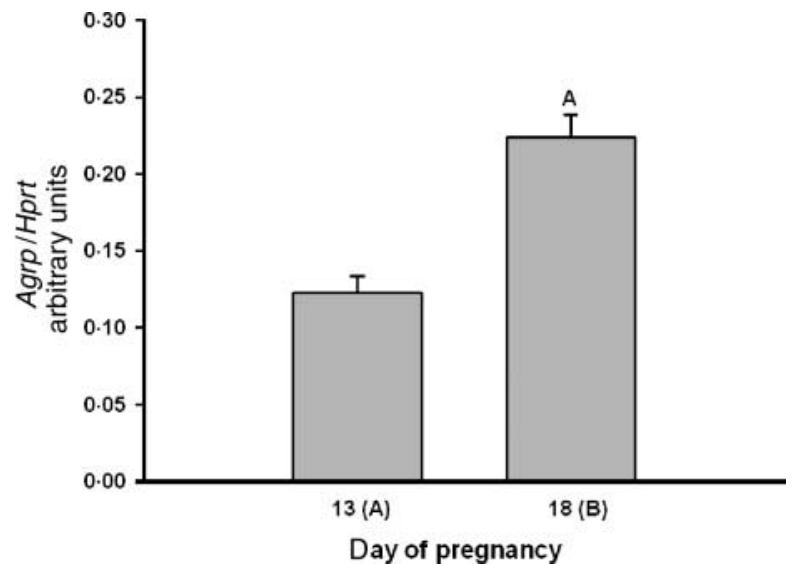

Figure 5 Changes in placenta expression of Agrp in the course of pregnancy. Statistically significant differences are marked with letters corresponding to the groups (small letters $-p \leq 0 \cdot 05$, capital letters $-P \leq 0 \cdot 01) . P=0 \cdot 05$ is not statistically significant.

We also found, using real-time PCR, immunocytochemistry (Fig. 3), and western blotting (Fig. 4) methods that AGRP was expressed in placenta on the 18th day of pregnancy. Moreover, the use of the real-time PCR allowed us to observe that the expression of Agrp was considerably higher on the 18th than on the 13th day of pregnancy (Fig. 5).

\section{Discussion}

In this study, we found that the Agrp expression significantly increased up to the 13th day of pregnancy and decreased on the 18th day. However, the Agrp mRNA level was still considerably higher than in control rats. Rocha et al. (2003) presented similar results showing that Agrp expression increased substantially in the hypothalamus during pregnancy. Furthermore, they found that another peptide, NPY, which is co-produced with AGRP by the same neurons and also regulates food intake, was not altered during pregnancy. Moreover, it was found that the injection of ghrelin agonist GH-releasing peptide 2 into the hypothalamus led to fat mass gain by AGRP in NPY-deficient animals (Tschop et al. 2002). These and previous data (Korner et al. 2001) may indicate that NPY and AGRP exert similar effects, but may be regulated differently. Also Ciofi et al. (1991) found that NPY was not changed during pregnancy. It may suggest that the AGRP may play a key role in the regulation of feeding during pregnancy.

It was found that Agrp expression in the hypothalamus was inhibited by leptin (Mizuno et al. 1999). During pregnancy, leptin level increased in the serum; however, mRNA level for the leptin receptor, both short and long forms, decreased (Amico et al. 1998, Garcia et al. 2000, Szczepankiewicz et al. 2006). These data may partly explain the increase of mRNA level for Agrp in the hypothalamus. On the other hand, we 
found that Agrp expression significantly decreased on the 18th day of pregnancy, although mRNA level was still higher than in control rats, in comparison with the rats on the 4th day of pregnancy.

Mechanisms responsible for the increase of food intake and retainment of positive energy balance during pregnancy are particularly important. Therefore, the decline in the expression of anorexigenic POMC peptides during pregnancy is obvious (Rocha et al. 2003). Rocha et al. (2003) also found significant changes in the melanocortin receptor 4 gene expression. However, the expression of this receptor was higher in pregnant than in control rats. This suggests that AGRP, as an antagonist of MC4R (Ollmann et al. 1997, Shutter et al. 1997), may be involved in the attenuation of POMC-derived peptides function during pregnancy. Furthermore, AGRP may act as an inverse agonist of MC4R (Haskell-Luevano \& Monck 2001, Breit et al. 2006) and contribute to food intake via this receptor. However, the competition between AGRP and MSH in melanocortin receptor binding has not yet been well known and may be associated with other factors such as syndecan-3 that acts as a co-receptor for MC4R in AGRP binding (Reizes et al. 2001). On the other hand, it was found that AGRP (83-132) acts as a competitive antagonist for human MC4R (Pritchard et al. 2004), suggesting a need for further exploration of these mechanisms.

The AGRP expressed in the hypothalamus may be associated with the regulation of brain energy homeostasis during pregnancy. We found that the AGRP serum level increased significantly during pregnancy. However, it was found that AGRP is frequently present as a trimer and crosses the blood-brain barrier very slowly (Kastin et al. 2000). It suggests that the peripheral AGRP is probably not responsible for a direct regulation of different peptides secretion in the brain. On the other hand, the Agrp expression in the hypothalamus decreased on the 18th day of pregnancy, while the AGRP level in the serum was significantly lower only after delivery. These data may suggest that another tissue may produce AGRP during pregnancy, and be responsible for its serum level. In addition, the hypothalamic AGRP may act particularly in a paracrine and autocrine manner. These data are in part consistent with the results obtained by Caminos et al. (2008), as they found that the Agrp expression in hypothalamus was the lowest on the 16th day of pregnancy in both groups of rats: those that were food restricted and those with access to food ad libitum.

In our study, we found that AGRP was expressed in placenta in mRNA as well as protein levels. Moreover, we found that the Agrp expression increased and was higher on the 18th day than on the 13th day of pregnancy. Similar results were obtained by Caminos et al. (2008) who also found that placental Agrp expression was significantly higher, but this increase was observed later, on the 21st day of pregnancy, and only in rats with access to food ad libitum, whereas in the group of food-restricted rats, Agrp expression in placenta increased significantly in all studied stages of pregnancy. Their results may indicate that increase of AGRP expression influences regulation of food intake, particularly during nutritional deficiency, being an important peptide responsible for maintenance of energy balance. However, results obtained by Beloosesky et al. (2006) indicated that Agrp expression decreased in rat placenta up to the 16th day of pregnancy, and was not observed on the 18th day. The reason for this inconsistency is unclear; however, their results have not been confirmed so far.

Our results imply that the placenta may be a source of AGRP in mother serum. Moreover, the AGRP serum level did not decrease before delivery, indicating that the placenta is a very important source of AGRP. However, AGRP was also found to be produced in other tissues such as the adrenal gland (Bicknell et al. 2000).

On the other hand, Nilsson et al. (2005) found that in the newborn mouse, the AGRP system in arcuate nuclei was not fully developed, and this process was not finished before the third postnatal week. They also suggested that the same action takes place in newborn rats. These results indicated that placental AGRP may also regulate fetal development. Although there are no data about AGRP crossing through placenta, this mechanism is possible.

In conclusion, we found that the AGRP expression in the hypothalamus and placenta, and its serum level increased during pregnancy. Moreover, the placenta may be the source of AGRP in the course of pregnancy. These data may indicate that this peptide acts as a key factor during pregnancy, for both mother energy expenditure and fetal development. As we have described previously, AGRP changes correlate positively with food intake increase during pregnancy (highest on the 18th day of pregnancy), but this increase was not significant (Szczepankiewicz et al. 2006). However, there are only few published data about changes of AGRP, MSH, and its receptors during pregnancy. Therefore, more experiments are required to confirm our findings.

\section{Declaration of interest}

There are no potential conflicts of interests.

\section{Funding}

D S is the recipient of a 2009 Annual Fellowship for Young Scientists from the Foundation for Polish Science (FNP).

\section{Authors' contribution}

D S, participated in the design of the study, tissue collections, protein isolation, and vaginal smear analysis, performed real-time PCR analysis, and drafted the manuscript. E P O, vaginal smear analysis, tissue collection, and RIA analysis. $\mathrm{P} K$, western blot analysis and statistical analysis. M S, vaginal smear analysis, RNA isolation, and reverse transcription. K A, 
immunocytochemistry. T W, tissue collection and RIA analysis. M S, tissue collections. $\mathrm{K} \mathrm{W} \mathrm{N}$, participated in the design of the study and coordinated the study.

\section{Acknowledgements}

DS was a participant in EMBO practical course 'Quantification of Gene Expression by qPCR' 17-22 June 2006, EMBL Heidelberg, Germany. Special thanks go to Dr Marcin Rucinski from the Department of Histology and Embriology, Poznan University of Medical Sciences for technical support.

\section{References}

Amico JA, Thomas A, Crowley RS \& Burmeister LA 1998 Concentrations of leptin in the serum of pregnant, lactating, and cycling rats and of leptin messenger ribonucleic acid in rat placental tissue. Life Sciences 63 1387-1395.

Beloosesky R, Gayle DA, Amidi F, Ahanya SN, Desai M \& Ross MG 2006 Ontogenic expression of putative feeding peptides in the rat fetal brain and placenta. Nutritional Neuroscience 9 33-40.

Bicknell AB, Lomthaisong K, Gladwell RT \& Lowry PJ 2000 Agouti related protein in the rat adrenal cortex: implications for novel autocrine mechanisms modulating the actions of pro-opiomelanocortin peptides. Journal of Neuroendocrinology 12 977-982.

Breit A, Wolff K, Kalwa H, Jarry H, Buch T \& Gudermann T 2006 The natural inverse agonist agouti-related protein induces arrestin-mediated endocytosis of melanocortin-3 and -4 receptors. Journal of Biological Chemistry 281 37447-37456.

Caminos JE, Bravo SB, Gonzalez CR, Garces MF, Cepeda LA, Gonzalez AC, Cordido F, Lopez M \& Dieguez C 2008 Food-intake-regulatingneuropeptides are expressed and regulated through pregnancy and following food restriction in rat placenta. Reproductive Biology and Endocrinology 614.

Chen P, Li C, Haskell-Luevano C, Cone RD \& Smith MS 1999 Altered expression of agouti-related protein and its colocalization with neuropeptide $\mathrm{Y}$ in the arcuate nucleus of the hypothalamus during lactation. Endocrinology 140 2645-2650.

Chen HY, Trumbauer ME, Chen AS, Weingarth DT, Adams JR, Frazier EG, Shen Z, Marsh DJ, Feighner SD, Guan XM et al. 2004 Orexigenic action of peripheral ghrelin is mediated by neuropeptide $\mathrm{Y}$ and agouti-related protein. Endocrinology 145 2607-2612.

Ciofi P, Fallon JH, Croix D, Polak JM \& Tramu G 1991 Expression of neuropeptide $\mathrm{Y}$ precursor-immunoreactivity in the hypothalamic dopaminergic tubero-infundibular system during lactation in rodents. Endocrinology 128 823-834.

Cowley MA, Pronchuk N, Fan W, Dinulescu DM, Colmers WF \& Cone RD 1999 Integration of NPY, AGRP, and melanocortin signals in the hypothalamic paraventricular nucleus: evidence of a cellular basis for the adipostat. Neuron 24 155-163.

Cowley MA, Smart JL, Rubinstein M, Cerdan MG, Diano S, Horvath TL, Cone RD \& Low MJ 2001 Leptin activates anorexigenic POMC neurons through a neural network in the arcuate nucleus. Nature $\mathbf{4 1 1} 480-484$.

Garcia MD, Casanueva FF, Dieguez C \& Senaris RM 2000 Gestational profile of leptin messenger ribonucleic acid (mRNA) content in the placenta and adipose tissue in the rat, and regulation of the mRNA levels of the leptin receptor subtypes in the hypothalamus during pregnancy and lactation. Biology of Reproduction 62 698-703.

Hahn TM, Breininger JF, Baskin DG \& Schwartz MW 1998 Coexpression of Agrp and NPY in fasting-activated hypothalamic neurons. Nature Neuroscience $1271-272$.

Haskell-Luevano C \& Monck EK 2001 Agouti-related protein functions as an inverse agonist at a constitutively active brain melanocortin-4 receptor. Regulatory Peptides 99 1-7.
Hoggard N, Johnstone AM, Faber P, Gibney ER, Elia M, Lobley G, Rayner V, Horgan G, Hunter L, Bashir S et al. 2004 Plasma concentrations of alpha-MSH, AgRP and leptin in lean and obese men and their relationship to differing states of energy balance perturbation. Clinical Endocrinology 61 31-39.

Kamegai J, Tamura H, Shimizu T, Ishii S, Sugihara H \& Wakabayashi I 2001 Chronic central infusion of ghrelin increases hypothalamic neuropeptide $\mathrm{Y}$ and agouti-related protein mRNA levels and body weight in rats. Diabetes $502438-2443$

Kastin AJ, Akerstrom V \& Hackler L 2000 Agouti-related protein(83-132) aggregates and crosses the blood-brain barrier slowly. Metabolism 49 1444-1448.

Kim EM, Grace MK, O'Hare E, Billington CJ \& Levine AS 2002 Injection of alpha-MSH, but not beta-endorphin, into the PVN decreases POMC gene expression in the ARC. Neuroreport 13 497-500.

Kojima M, Hosoda H, Date Y, Nakazato M, Matsuo H \& Kangawa K 1999 Ghrelin is a growth-hormone-releasing acylated peptide from stomach. Nature 402 656-660.

Korner J, Chua SC Jr, Williams JA, Leibel RL \& Wardlaw SL 1999 Regulation of hypothalamic proopiomelanocortin by leptin in lean and obese rats. Neuroendocrinology 70 377-383.

Korner J, Savontaus E, Chua SC Jr, Leibel RL \& Wardlaw SL 2001 Leptin regulation of Agrp and Npy mRNA in the rat hypothalamus. Journal of Neuroendocrinology 13 959-966.

Mizuno I, Okimura Y, Takahashi Y, Kaji H, Abe H \& Chihara K 1999 Leptin stimulates basal and GHRH-induced GH release from cultured rat anterior pituitary cells in vitro. Kobe Journal of Medical Sciences 45 221-227.

Nilsson I, Johansen JE, Schalling M, Hokfelt T \& Fetissov SO 2005 Maturation of the hypothalamic arcuate agouti-related protein system during postnatal development in the mouse. Brain Research Developmental Brain Research 155 147-154.

Ollmann MM, Wilson BD, Yang YK, Kerns JA, Chen Y, Gantz I \& Barsh GS 1997 Antagonism of central melanocortin receptors in vitro and in vivo by agouti-related protein. Science 278 135-138.

Pfaffl MW, Tichopad A, Prgomet C \& Neuvians TP 2004 Determination of stable housekeeping genes, differentially regulated target genes and sample integrity: BestKeeper-Excel-based tool using pair-wise correlations. Biotechnology Letters 26 509-515.

Pritchard LE, Turnbull AV \& White A 2002 Pro-opiomelanocortin processing in the hypothalamus: impact on melanocortin signalling and obesity. Journal of Endocrinology 172 411-421.

Pritchard LE, Armstrong D, Davies N, Oliver RL, Schmitz CA, Brennand JC, Wilkinson GF \& White A 2004 Agouti-related protein (83-132) is a competitive antagonist at the human melanocortin-4 receptor: no evidence for differential interactions with pro-opiomelanocortin-derived ligands. Journal of Endocrinology 180 183-191.

Reizes O, Lincecum J, Wang Z, Goldberger O, Huang L, Kaksonen M, Ahima R, Hinkes MT, Barsh GS, Rauvala H et al. 2001 Transgenic expression of syndecan-1 uncovers a physiological control of feeding behavior by syndecan-3. Cell 106 105-116.

Rocha M, Bing C, Williams G \& Puerta M 2003 Pregnancy-induced hyperphagia is associated with increased gene expression of hypothalamic agouti-related peptide in rats. Regulatory Peptides 114 159-165.

Schwartz MW, Baskin DG, Bukowski TR, Kuijper JL, Foster D, Lasser G, Prunkard DE, Porte D Jr, Woods SC, Seeley RJ et al. 1996 Specificity of leptin action on elevated blood glucose levels and hypothalamic neuropeptide Y gene expression in ob/ob mice. Diabetes 45 531-535.

Schwartz MW, Seeley RJ, Woods SC, Weigle DS, Campfield LA, Burn P \& Baskin DG 1997 Leptin increases hypothalamic pro-opiomelanocortin mRNA expression in the rostral arcuate nucleus. Diabetes 46 2119-2123.

Seoane LM, Lopez M, Tovar S, Casanueva FF, Senaris R \& Dieguez C 2003 Agouti-related peptide, neuropeptide $\mathrm{Y}$, and somatostatin-producing neurons are targets for ghrelin actions in the rat hypothalamus. Endocrinology 144 544-551.

Shaw AM, Irani BG, Moore MC, Haskell-Luevano C \& Millard WJ 2005 Ghrelin-induced food intake and growth hormone secretion are altered in melanocortin 3 and 4 receptor knockout mice. Peptides 26 1720-1727. 
Shutter JR, Graham M, Kinsey AC, Scully S, Luthy R \& Stark KL 1997 Hypothalamic expression of ART, a novel gene related to agouti, is up-regulated in obese and diabetic mutant mice. Genes and Development 11 593-602.

Szczepankiewicz D, Wojciechowicz T, Kaczmarek P \& Nowak KW 2006 Leptin and its receptors in the course of pregnancy in the rat. International Journal of Molecular Medicine 17 95-99.

Tang-Christensen M, Vrang N, Ortmann S, Bidlingmaier M, Horvath TL \& Tschop M 2004 Central administration of ghrelin and agouti-related protein (83-132) increases food intake and decreases spontaneous locomotor activity in rats. Endocrinology 145 4645-4652.

Thornton JE, Cheung CC, Clifton DK \& Steiner RA 1997 Regulation of hypothalamic proopiomelanocortin mRNA by leptin in ob/ob mice. Endocrinology 138 5063-5066.

van den Top M, Lee K, Whyment AD, Blanks AM \& Spanswick D 2004 Orexigen-sensitive NPY/AgRP pacemaker neurons in the hypothalamic arcuate nucleus. Nature Neuroscience 7 493-494.
Tschop M, Statnick MA, Suter TM \& Heiman ML 2002 GH-releasing peptide-2 increases fat mass in mice lacking NPY: indication for a crucial mediating role of hypothalamic agouti-related protein. Endocrinology 143 $558-568$.

Witschi E 1962 Development: rat. In Growth Including Reproduction and Morphological Development, Eds PL Altman \& DS Dittmer. Washington, DC, USA: Biological Handbooks of the Federation of American Societies for Experimental Biology.

Yeo GS, Farooqi IS, Aminian S, Halsall DJ, Stanhope RG \& O'Rahilly S 1998 A frameshift mutation in MC4R associated with dominantly inherited human obesity. Nature Genetics 20 111-112.

Received in final form 27 April 2009

Accepted 29 April 2009

Made available online as an Accepted Preprint 29 April 2009 